\title{
THE UTILIZATION OF FLASHCARDS IN TEACHING ENGLISH TO YOUNG LEARNERS
}

\author{
Novi Nuryani' ${ }^{1}$, Odo Fadloeli ${ }^{2}$ \\ 1,2 IKIP Siliwangi \\ ${ }^{1}$ nonov@student.ikipsiliwangi.ac.id, ${ }^{2}$ odofadloh@gmail.com
}

\begin{abstract}
Media in learning process is very intact because it will be supported from the learning to be more easily exposed. Many experts say that with the media, it can help teachers and students in the learning process to be able and achieve the goals of the learning process. This research aimed it introducing and describing how the preparation and utilization of the flashcards media are used by teachers in teaching English to young learners. This research was conducted at SDN Baros Mandiri 2 Cimahi. The method used in this research is the descriptive research in accordance with the case study that occurred. The source of the data was the English teacher and the subjects were the second grade students of SDN Baros Mandiri 2 Cimahi. Observation, interviews and documentation are the data collection techniques used in this research. The findings reveal that teachers use flashcard media according to the material to be delivered to young learners. Based on the results of the research the flashcard media can help facilitate teachers in the delivery of learning material, students are also more enthusiastic, excited and very happy to learn English and very influential in the teaching and learning process.
\end{abstract}

Keywords: Instructional Media, Utilization of Instructional Media, Flashcard

\section{INTRODUCTION}

The function of language is as a communication tool, because that language has a very important role. Efransyah (2020) has stated that Language is a means of communication that is used to transfer information, ideas, and feelings from one person to another. It is used to communicate both in written and spoken form. As times goes by, the development in communication has increased all over the world. One of the languages that must be learned in this era of globalization is English, which is also referred to as second language because English is the target language that is intentionally learned with a specific purpose. The development of English is not only as a foreign language or an international language that must be learned, English is as skill which very necessary to master knowledge, and communicate both orally and in written form.

The ministry of Education and Culture of Republic of Indonesia No. 23 of 2006 stated that elementary schools can make English a subject of local content. Therefore, English at the elementary school level is a local content that must be learned by students. In addition to requirement to communicate properly the goal is that the students have an awareness of the true importance of English. To obtain these objectives, the learning process must be carried out interactively, inspiratively, fun supported by the use of media that can motivate students to actively participate in learning.

When learning English is often faced with several problems from students, they lack of students' motivation in learning, feeling bored with learning English that makes them confused. According to Muhyiddin (2019) most teachers don't assume that it is important for English to 
study in the elementary school. Consequently every teacher who is not competent in teaching English can teach it. Because of this, there will be a lot of misunderstanding or errors in teaching English. The teacher has an important role because it will guide students to be able to read, listening, speaking and writing. One of the main problems faced by teachers when teaching English is that teachers do not use the right methods and approaches. Therefore, the teacher is responsible for determining the method, and what media will be used when learning process goes on.

"Everything that can be used to channel messages from the sender to the recipient so as to stimulate thoughts, feelings, in the learning process is referred to as the media" (Lindiawati, 2018). When a teacher conveys a message or material in teaching learning process, students are les to understand and comprehend what the teacher conveys. In this case, the media can help teachers and students in the teaching and learning process. Muhyiddin (2019) has stated that teaching English to young learners needs media to help the teachers to deliver the materials since the media is the channel of communication. The media are helpful in delivering information and can help to make the teaching process simple and perfect.

Lots of media can be used in the teaching and learning process, especially visual media. One of the visual media that can be given by the teacher to students is flashcards media. According to Kusumawardani (2019) Flashcard is a picture card complemented by words launched by Glenn Doman, a brain surgeon from Philadelphia, Pennsylvania, those cards shown to children then read every sentence on each card. The cards are usually designed with such attractive colors and images animals, fruits, colors, shapes, alphabet, numbers, professions. Muhyiddin (2019) also states that Flashcard media not only improves the ability to listen, speak read and write but flashcards can also train students' abilities in vocabulary, pronunciation, grammar, spelling. Based on this opinion, it can be explained that the size of the flashcards can be adjusted to the situation of students faced, if the number of students is large then the flashcard is made with a larger size, and if the number of students is small then the flash scards is made with a small size. With the pictures used in the card the images can be adjusted to what material will be conveyed by the teacher to students.

Harahaf and Zulfitri (2019) argue that a good media is a media which is suitable for the topic, the material, the students, and practical to use. Based on the opinion, it can be concluded that before applying a media, the teachers should know what are the preparations and how the utilization of the media in classroom. According to Susilana, and Riyana (2009: 96) in Lindiawati (2018), there are several steps that must be prepared in the use of flashcards media they are :

1) Preparing yourself, the teacher should understand the teaching materials that will be delivered to the students and have the skills to use the media flashcard.

2) Preparing the flashcards media, to ensure that the media is reday so that it does not need other media in the classroom.

3) Preparing place, this relates to the position of the teacher that students can see the flashcard from all directions.

4) Preparing the student, their seats are arranged prooperly, so that they can pay attention to learning, material delivered with a flashcards.

There are things that must be considered when utilizing flashcards media accroding to Susilana, and Riyana (2009: 96) in Lindiawati (2018):

1) The cards that have been arranged in a holding at chest level.

2) Take the cards after the teacher has finished explaining the material. 
3) Give cards to students observed, then pass them on to nother students so that they all can see the cards.

4) If the use of media in the form of the game, keep the cards on the box randomly, and then the students will arrange the cards.

This opinion was supported by Khoiriyah (2013: 17) cited in Kusumawardani (2019), she stated that in the utilization of flashcard before using this media, the teacher should known in advance the material to be studied and then adapted to the media, and then show and give the cards to the students to be observed and ensure all the students get to observe the cards. So it can be said that the media cannot be seen from the price, whether it is cheap or not, but it is seen from the media related with the material, and steps in their utilization are adjusted to the needs in learning process, that is interesting and able to help the teacher in creating fun and effective learning in the classroom. This study aims to find out what the preparations and utilization for the use of flashcard media as learning media are carried out in the classroom. To achieve the objective of the research, the researcher questions are formulated in this study How are the preparation of the teacher and teacher utilizes the flashcard in teaching English in the classroom?

\section{METHOD}

In this study the writer used observation, interview, and documentation in the class rooms. Interviews are techniques data collection conducted by researchers to find problems that must be examined, or to find out things from respondents in more depth (Sugiyono, 2015: 231) cited in Wicaksono (2018). Interviews were conducted to obtain information from speakers as English teacher at SDN Baros Mandiri 2 Cimahi related to personal data and preparation and utilization of flashcards learning media in second grade of elementary school. Interview itself consists of formal and informal. Formal is utilized after the entire of the perception, while the casual meeting was utilized in perception. Observation activity was carried out to retrieve real information that is adjusted to the reality in the field. Sugiyono (2015) in Wicaksono (2018) has stated that observation is a technique data collection that has specific characteristics that are not separated from people but also other natural objects, Observations were made to find out the real situation in class when the process of learning English using flashcard media. From the result of interview and observation of documentation to collecting the data.

\section{RESULTS AND DISCUSSION}

\section{Results}

From the interview, observation and documentation the writer got information that one of the English language teachers at SDN Baros Mandiri 2 Cimahi was named MustikaYuliani S. Pd, a graduate from IKIP Siliwangi in 2016. She taught English in this school for only 5 months. Facilities at the school are sufficient to support teaching and learning activities such as blackboards, teaching aids and others. However, facilities for learning English itself are felt to be lacking so in this case the teacher should be creative to making media as a support to facilitate learning.

The teacher chooses the flashcard media because the material will be delivered to the students relevan when using this media and this media is very practical, interesting to use in the classroom. Widya, Yuliana and Sofiani (2018) has stated that Flashcards is the practical media to help teachers and students in the teaching and learning process, especially to teach students. 
During the preparation process, the teacher does not find difficulties in making the media. Before the learning process begins, the teacher tries to analyze the characteristics of students abilities, see and read what the material will be conveyed for learning. And then the teacher chooses learning media adjusted to the material to be taught to students. In this study the teacher chose flashcard learning media for learning prepositions of place. The teacher should prepare and have the skills to use the flashcard media.

For the utilizes action of flashcard media named in English learning about the preparation of place the teacher uses cards that are not so large for class size and the number of students, so the learning process looks less conducive because when the teacher shows the card students must stand up, or walk to front, sometimes the teacher has to approach that the images on the card can be seen by students.

Below is an observation sheet used by the researcher at the time of observation.

Table 1. Observation Sheet

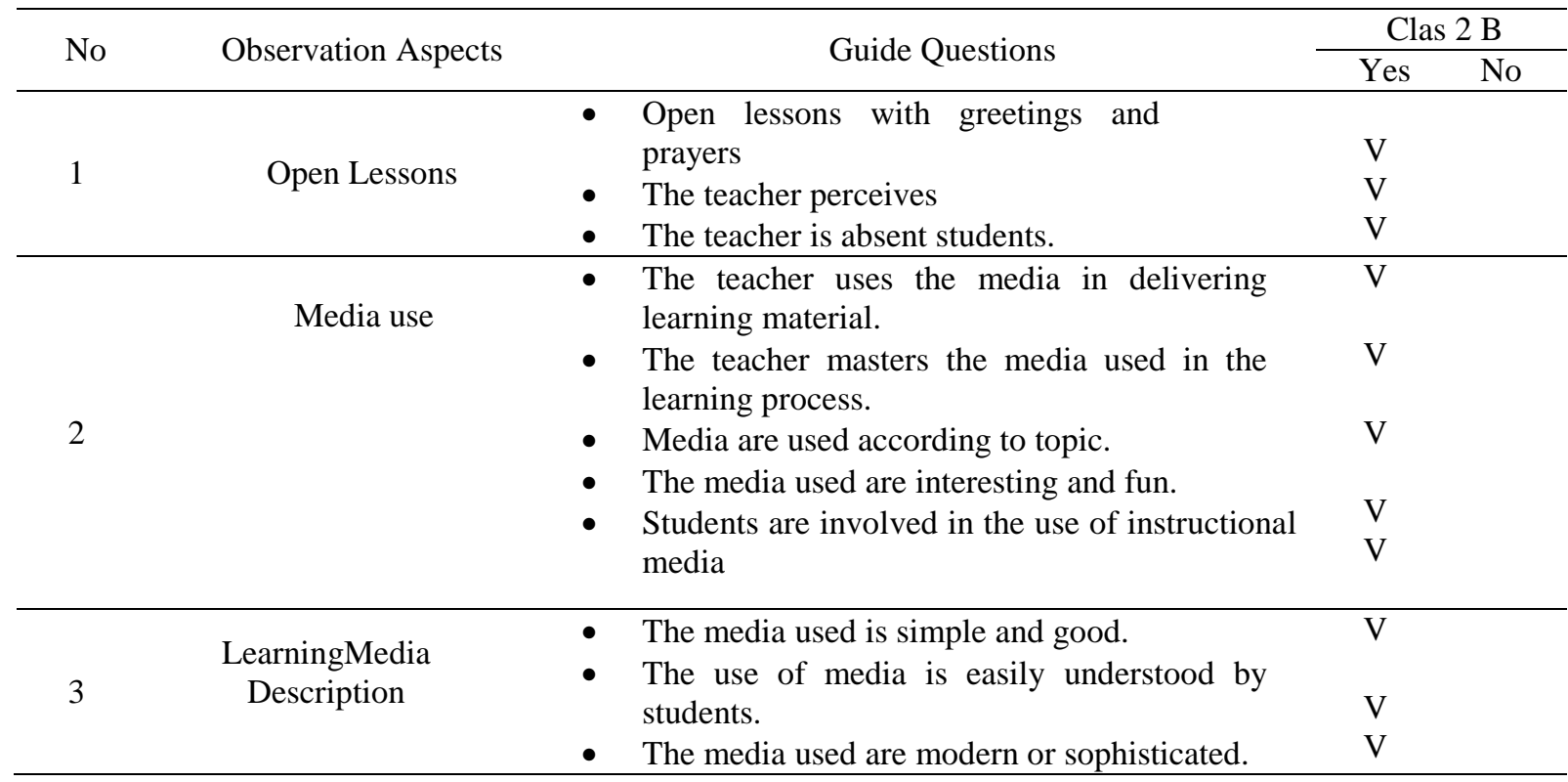

\section{Discussion}

Related to the resuls of the interview with the English teacher in the second grade of elementary school in SDN Baros Mandiri 2 Cimahi and what we have seen in the calssroom, can be explained that related with the same opinion who explained in preparation of flashcards media should prepare anything such as preparing the material to be learnd, know how the characteristic of students, preparing classroom for doing teaching and learning process Susilana, and Riyana (2009: 96) in Lindiawati (2018). Although this media is very practical, can be used from all levels. However the teacher should prepare anything that is needed it to create a learning process that has been previously planned. So according to the theory above, the preparation of the flashcard media that will be used by the teacher as a tool to help the learning process in class is the same. It can be seen from how the teacher prepared everything such as preparing himself, the media, the place and of course students. 
According to Indrasari, Novita and Megawati (2018) children can learn from everything about what is around them, they are not easy to understand from explanation and often they get bored easily and teaching children is not easy and is very different from teaching adults. The teacher or educator of young learners must be able to provide something that can attract their interest and conservation such as fun activities, interesting media.

"There are so many ways and media that can be used to help the learning process, so that the message delivered to students can be understood by students"Ardiyanti, Usman and Bandu (2018). The teacher is easy to convey, students are more enthusiastic about the learning process. In choosing media, the teacher adjusts to what material will be taught to students, like learning about preparation of place delivered to the student teacher using flashcards as a media. The prepared tools and materials are meant to make learning facilities such as glue, boxes, and learning drawings that have been printed according to the material that will be given. And as for how to make flashcard media, the teacher looks for sources through the internet and then downloads some images related with the needs, and then printed and pasted thicker materials, such as cardboard.

Before using this media not only the class, but also the teacher prepares the students who will follow the learning process. The teacher arranges the student's seat so that later during the study the students can follow the learning comfortably, students pay attention to the material presented the flashcard media used to be seen from various directions.

The utilization activities carried out by the teacher in the classroom in accordance with the opinion of Susilana and Riyana (2009: 96) in Lindiawati (2018) has stated that There are things that must be considered when utilizing flashcard media: The cards that have been arranged in a holding at chest level, take the cards after the teachers has been finished with material to give cards to students observed, and then pass them on to another students so they all can see the cards. The last, If the use of media in the form of the game is finished, keep the cards on the box randomly, and then the students will arrange the cards.

For the use of flashcard media related to first of all the teachers explains in advance the material that will be given, when students are given material about the preparation of place students retain the material written and explained by the teacher. The teacher writes some vocabulary related to the materials such as on, in, between, behind, beside, etc. And the teacher gives at least five questions to the students in the classroom.

And then the teacher takes the picture on the flashcard and then gives questions to students about the position of the ball in the flashcard image for example where is the ball? students pay attention to the picture held by the teacher and then answer where the object's position is, for example the ball is in the box. The position of the teacher in front of class, and the teacher show the flashcard media in a holding at chest level.

Sometimes because the media used is not large enough the teacher walks arounds to give some picture in the cards to students observed, then pass them on to another student so they all can see the cards. At the learning process in the classroom the use of this media is not form of the game because this activity was carried out in second grade, it was feared that the learning process would not be conducive. 
When learning English in the classroom which is about the preparation of place, the teacher uses flashcard media in accordance with the theory mentioned earlier. The teacher just stands in front of the class showing a chest-high card, but sometimes walks toward the student to show the cards. However, in this utilization there is a slight difference between theory and the use of media carried out by the teacher in the classroom. The teacher does not use this media in the form of games, because the students in the class are very active, the media used are also not too large, students often stand when the teacher shows cards so that learning is less conducive. In the use of flash media cards the teacher must carry out activities such as what will be done, in what form the media and material are delivered in class, so the teacher can provide and prepare the material for students properly and students will receive the material.

\section{CONCLUSION}

Based on the results of the research, it can be concluded that the use of media has an important role in the learning process. The writer tries to answer some questions about the preparation of media use and ways to utilization for teachers to use the flashcards media when learning English to young learners. In the initial stages the teacher must prepare the media systematically so as to create benefits from the media used. Preparation of the teacher to set Flashcard by preparing everything needed by first understanding the material to be delivered according to the media to be used, the tools and materials to make the media. And the utilization of the flashcard media used by the teacher in the classroom. In the field the flashcards media can help facilitate teachers in the delivery of learning material, students are also more enthusiastic, excited and very happy to learn English and make them dare to advance to appear in front of the class. So that a positive interaction occurs both the teacher with the rest, students, and students with learning media.

\section{ACKNOWLEDGMENTS}

Thank You to Allah SWT the almighty until now You always give we health, finally the writer is able to complete this research. Thanks to my parents and friend who always pray and give me support to finish this article. The writer would like to say the biggest thank you for my article supervisors who always gave the writer support, check in carefully conducting this research. Also, the writer would like to say thanks you to SDN Baros 2 Cimahi as a palce to do this research, and do not forget Miss Mustika Yuliani as one of the teachers English and for all students of second grade of elementary school in this school that is already willing to become a resource person and subject for this research.

\section{REFERENCES}

Ardiyanti., A. Usman., M. \& Bandu. (2018). Learning Vocabulary France Language with Flsash Cards Media ( Case Study in France Students Literature). Jurnal Ilmu Budaya, Vol. 6, No 1.

Efransyah. (2020). Conotative meaning in the Provers of the Basemah Language (A Sematic Study). PROJECT (Professional Journal Of English Study), Vol. 3, No. 1.

Harahap \& Zulfitri . (2019). Penerapan Media Flashcard dalam bahasa Inggris untuk meningkatkan kemampuan Kosakata bahsa Inggris siswa TK Setia Budi Abadi Perbaungan. Prosiding seminar Nasional hasil Pengabdian .

Muhyiddin, I. (2019 ). The Effectiveness of using Flashcard to Teach Vocabulary at Elementary School. REPOSITORI INSITUSI Universitas Islam Majapahit , 18-29 thesis. 
Indasari, A., Novita, D., and Megawati. (2018). Big Book: Attractive Media for Teaching Vocabulary to Lower class of Young Learners. JEES (Journal of English Education Society), vol 3 no 2.

Kusumawardhani, P. (2019) The Use of Flashcards for Teaching Writing to English Young Learners (EYL). UNINDIRA: Journal of English Language Teaching, Vol.4, No. 1. 35-52.

Lindiawati, N. P. (2018). Keefektifan pengajaran Kosakata bahasa Inggris pada anak Sekolah Dasar dengan menggunakan Flah Card. Jurnal manajemen pelayanan hotel akademi komunitas Perhotelan Indonesia, vol 2 no 2.

Merriam,S.\&.Tidel(2015). Qualitative research: A guide to design and implementation.fourth edition. san Fransisco : Jossey- Bass.

Wicaksono, H. (2018). Utilization of E- Journal By Students in the Library Higher Education in Jakarta. Lentera Pustaka: Journal Kajian Ilmu Perpustakaan, Informasi dan Kearsipan. , Vol. 4, No. 2.

Widya, Yuliana \& Sofiani. (2018). Pengajaran kosakata Bahasa Inggris dengan Media Realia dan Flashcard. Jurnal PKM: Pengabdian Kepada Masyarakat, Vol. 01, No. 01. 3947. 